\title{
$12 \times 6$ Gy stereotactic radiotherapy for lung tumors. Is there a difference in response between lung metastases and primary bronchial carcinoma?
}

\author{
Dorota Lubgan $^{1}$ (D) - Sabine Semrau ${ }^{1}$. Ulrike Lambrecht ${ }^{1} \cdot$ Udo S. Gaipl $^{1} \cdot$ Rainer Fietkau $^{1}$ \\ Received: 8 March 2021 / Accepted: 18 June 2021 / Published online: 13 July 2021 \\ (c) The Author(s) 2021
}

\begin{abstract}
Purpose The aim of this study was to evaluate the safety and long-term tumor control after stereotactic radiotherapy (SRT) with $12 \times 6$ Gy of patients with primary bronchial carcinoma (BC) or with pulmonary metastases (MET) of various solid tumors. Local progression-free survival (LPFS), progression-free survival (PFS), overall survival (OS), and prognostic factors were compared.

Methods Between May 2012 and January 2020, 168 patients with 206 pulmonary lesions (170 MET and 36 primary BC) were treated with $12 \times 6 \mathrm{~Gy}\left(\mathrm{BED}_{10} 116 \mathrm{~Gy}\right)$. The irradiated pulmonary MET were from the following cancers: $47(27.6 \%)$ head and neck, 37 (21.8\%) rectum or colon, $30(17.6 \%)$ bronchial, 13 (7.6\%) malignant melanoma, 9 (5.3\%) esophageal, $9(5.3 \%)$ sarcoma, and $25(14.8 \%)$ other.

Results The median follow-up was 16.26 months (range: 0.46-89.34) for BC and 19.18 months (0.89-91.11) for MET. Survival rates at 3 years were: OS $43 \%$ for BC and 35\% for MET; LPFS BC 96\% and MET 85\%; PFS BC 35\% and MET 29\%. The most frequently observed grade 3 adverse events (AEs) were pneumonitis (5.9\% BC, 4.8\% MET), pulmonary fibrosis $(2.9 \% \mathrm{BC}, 4 \% \mathrm{MET})$, and pulmonary embolism (2.9\% BC, $0.8 \% \mathrm{MET})$. The favorable prognostic effects on overall survival of patients with MET were female gender (log-rank: $p<0.001)$, no systemic progression (log-rank; $p=0.048$, multivariate COX regression $p=0.039$ ), and malignant melanoma histology (log-rank; $p=0.015$, multivariate $\mathrm{COX}$ regression $p=0.020$ ). For patients with $\mathrm{BC}$, it was tumor location within the lower lobe (vs. upper lobe, log-rank $p=0.027$ ). LPFS of patients with metastatic disease was beneficially influenced by female gender (log-rank: $p=0.049$ ).

Conclusion The treatment concept of $12 \times 6 \mathrm{~Gy}$ is associated with $96 \%$ local progression-free survival for BC and $85 \%$ for pulmonary metastases after 3 years. There was no difference in response after SRT of primary lung carcinoma or pulmonary metastases.
\end{abstract}

Keywords Pulmonary lesion $\cdot$ Primary lung cancer $\cdot$ Stereotactic irradiation $\cdot$ Prognostic factor $\cdot$ Progression-free survival

\section{Introduction}

Lung cancer is one of the most common cancers worldwide. The lungs are the second most frequent site of metastasis of various types of solid cancer. Lung metastases are frequent in head and neck cancer, gastrointestinal tumors, malignant melanoma, renal carcinomas, different types of sarcomas, and bronchial carcinoma (BC) itself [1]. Surgery is the standard for treatment of medically operable

Dorota Lubgan

dorota.lubgan@uk-erlangen.de

1 Department of Radiation Oncology, Erlangen University Hospital, Universitätsstraße 29, 91054 Erlangen, Germany early-stage bronchial carcinoma [2] and oligometastatic pulmonary metastases [3]. Stereotactic radiotherapy (SRT) has become the preferred treatment option for medically inoperable bronchial carcinoma patients [4] with significant comorbidities, or for patients who decline surgery [5]. Locally advanced non-small-cell lung cancer (NSCLC) remains a challenging disease with persistently poor outcomes. Standard treatment for metastatic disease (MET) has historically been systemic chemotherapy. Evidence drawn from retrospective series have documented how patients with a limited pattern of disease showed improved long-term outcomes when submitted to local aggressive treatment [6]. Stereotactic radiotherapy delivers rapid and non-invasive high doses to target tumor with sparing of surrounding normal tissues. This seems to provide good 
results in terms of control of disease [7]. Successful local therapy for pulmonary lesions may lead to longer survival. Recent studies performing SRT of lung metastases showed high rates of local control and a low incidence of severe (grade 3-5) toxicities [8].

However, the effectiveness of SRT seems to depend not only on the irradiation protocols, but also on the pattern of development of the tumor state or distinct prognostic factors. The aim of this study was therefore to evaluate the safety and long-term tumor control of the Erlangen stereotactic radiotherapy concept with $12 \times 6$ Gy for patients with primary bronchial carcinoma (BC) or pulmonary metastases. We have analyzed the severity of acute and chronic adverse events, overall survival, and progression-free survival (local at irradiated lesion and systemic), and identified prognostic factors. This study differs from many other studies in the aspect that the patients with primary therapy of primary bronchial carcinoma and patients with lung metastases of various solid tumors were evaluated separately and compared to each other.

\section{Materials and methods}

\section{Study design}

\section{Patient selection}

Of 171 intended patients, 168 received $100 \%$ of the planed irradiation dose $(72 \mathrm{~Gy})$. For three patients with metastatic disease, we could not apply the planned dose from the beginning for reasons of radiation protection. This study was analyzed in a retrospective setting; therefore, we decided to regard the 168 patients/206 lesions as 100\% (Fig. 1).

The analysis was performed by defining two efficacy subsets related to the irradiated metastases (124 patients with 170 metastases) or primary bronchial carcinoma (34 patients with 36 primary lesions). The patients were treated between May 2012 and January 2020 at the Department of Radiation Oncology of the university hospital by stereotactic irradiation. The study was conducted in accordance with the current version of the Declaration of Helsinki [9] and according to the Good Clinical Practice [10].

\section{Treatment planning}

SRT was performed using the dedicated stereotactic radiosurgery systems Novalis ${ }^{\mathrm{TM}}$ (BrainLAB, Feldkirchen, Germany) and Vero ${ }^{\mathrm{TM}}$ (BrainLAB). The dose was prescribed according to ICRU guidelines. A total dose of $72 \mathrm{~Gy}$ in 12 fractions of $6 \mathrm{~Gy}$ was given daily on consecutive workdays. GTV (gross tumor volume) was defined as the enhancing tumor mass (GTVUnion) based on a respirationcorrelated computer tomography (CT) study. PTV (planning target volume) as the GTVUnion with a 5-mm margin in left-right and anteroposterior directions and a 7-mm margin in the craniocaudal direction. The dose was prescribed on an isodose surface $(80 \%)$ that encompassed at least $95 \%$ of the PTV. The maximum dose within the PTV

Fig. 1 Flowchart of the study

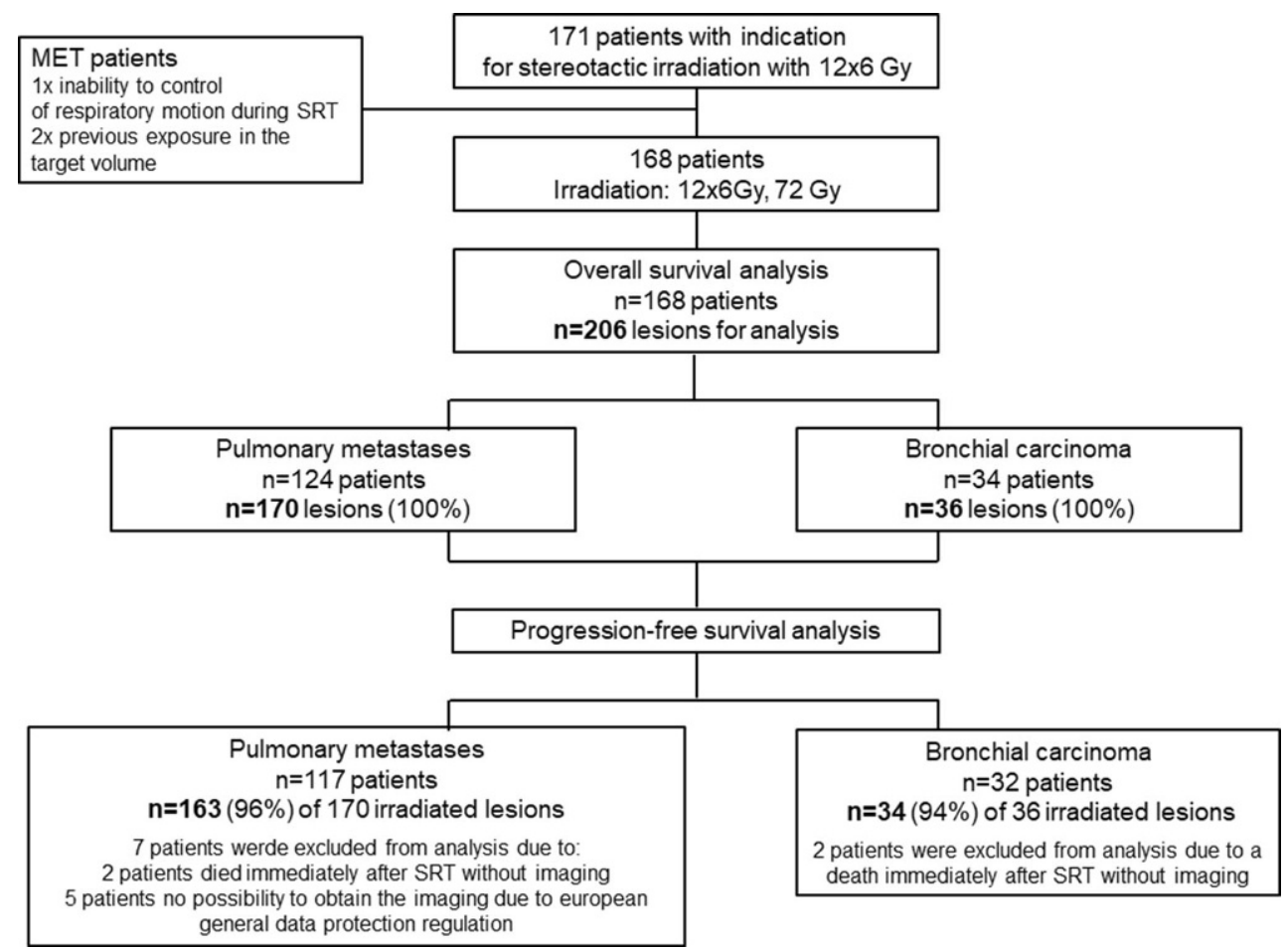


on a small volume of max $1 \mathrm{ccm}$ was approximately $125 \%$ of the prescribed dose. Organs at risk, i.e., esophagus, heart, and spinal cord, were contoured according to the CT imaging. The treatment was conducted image guided at deep expiration with breathing commands. CT scans were performed immediately prior to STR and on days 1,3 , and 8 at maximal inspiration, maximal expiration, or during breathing baseline. The target volume was adapted in case of deviations from planning CT.

\section{Outcome measurements and statistical analysis}

Progression-free survival (local at irradiated lesion and systemic) was assessed through repeated CT, sometimes with additional positron-emission tomography (PET-CT) and magnetic resonance imaging (MRI), according to the standard of care. Local progression-free survival (LPFS) was evaluated using the RECIST criteria as previously described [11]. The study used the International Common Terminology Criteria for Adverse Events (CTCAE) version 4.0 for toxicity and adverse events reporting. A specially designed standardized questionnaire was used by the physician to collect the toxicity data during the clinical visits at the time of irradiation and at follow-up.

Continuous variables were evaluated using descriptive statistics. Unless indicated otherwise, results are presented as mean $\pm \mathrm{SD}$ and/or median with ranges. Standard sum- mary statistics and two-tailed $95 \%$ confidence intervals (CI) were calculated as appropriate. All statistical analyses were performed using the Statistical Package for the Social Sciences (SPSS) version 24 (IBM Corp., Armonk, NY, USA). The level of significance for all analyses was set at $\alpha=0.05$ (two-tailed). For identification of the prognostic factors after SRT, the patient data were analyzed according to age, sex, number and location of irradiated lesions in the lung, histology, presence of other distant metastases at the irradiation timepoint, application of a concurrent systemic therapy regimen, PET-CT diagnostics prior to irradiation, and the presence of local or distant progression. The strength of the association between two variables was estimated according to Pearson [12]. Local progression-free survival (LPFS), progression-free survival (PFS), and overall survival (OS) were estimated with the Kaplan-Maier method [13], compared with the log-rank test [14], and modelled with the Cox hazard method (uni- and multivariate) [15]. Variables for which $p<0.3$ in univariate analysis were selected for multivariate logistic regression. The date of progression was selected as the date of the first event, including local progression (a 20-percent increase in size determined by CT imaging compared to size at the end of SRT), or newly diagnosed distant metastases (from the beginning of stereotactic irradiation). Overall survival was defined as the time from the first day of irradiation until death due to any cause. Surviving patients were censored at date of last contact.
Fig. 2 a Allocation of the lesions to the area of the lung for patients with metastases (black) and with bronchial carcinoma (red). b Number of irradiated lung lesions per patient

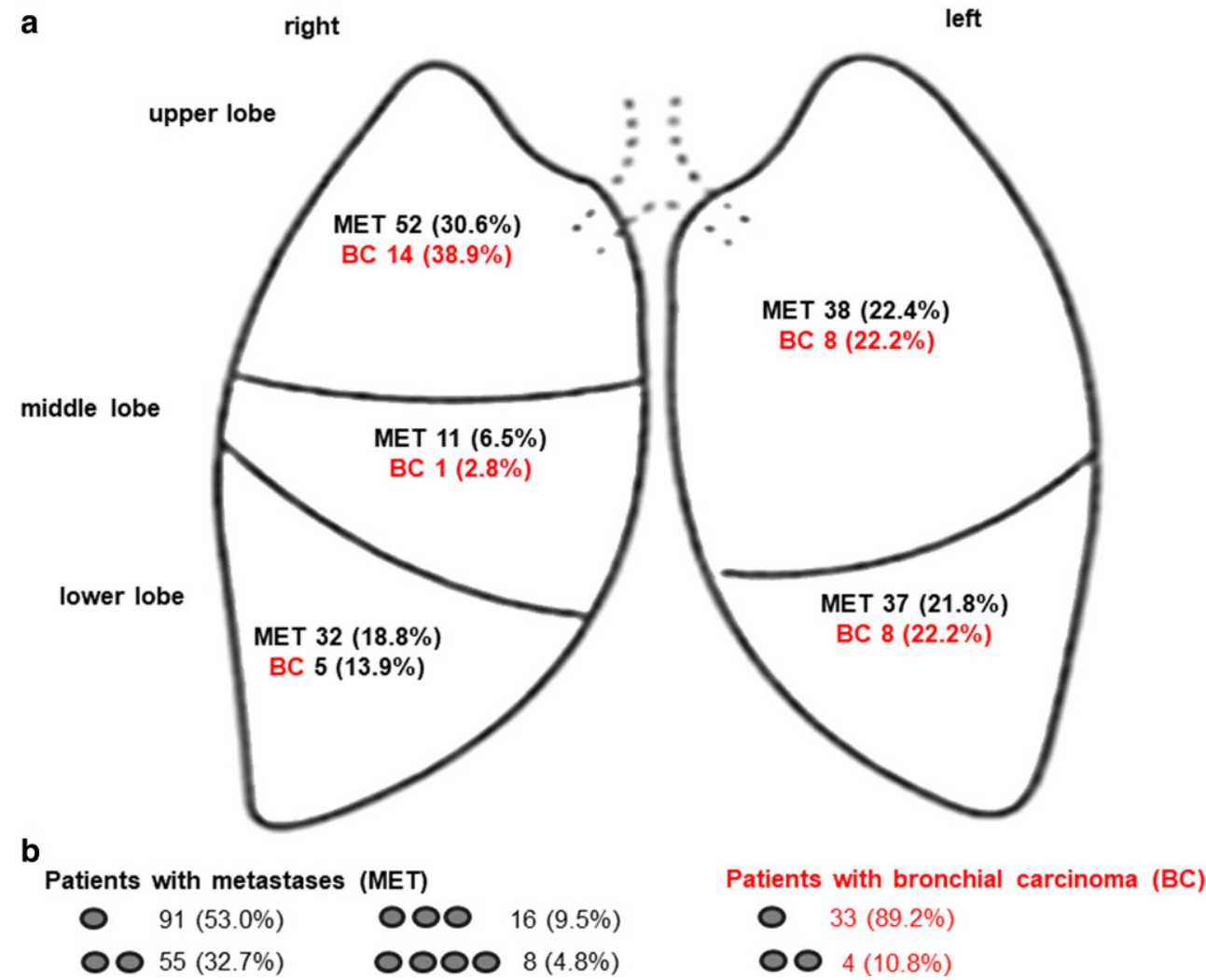


Table 1 Patient characteristics

\begin{tabular}{lll}
\hline $\begin{array}{l}\text { General data/medical } \\
\text { history }\end{array}$ & Metastases (MET) & $\begin{array}{l}\text { Bronchial carci- } \\
\text { noma (BC) }\end{array}$ \\
& $n=170$ lesions, & $n=36$ lesions, \\
& $n=124$ patients & $n=34$ patients \\
\hline
\end{tabular}

Age a beginning of RT (years)

$\begin{array}{ll}\text { Mean } \pm \text { SD } & 65.79 \pm 11.03 \\ & p=0.175 \\ \text { Median (range) } & 64.50(33-90) \\ & p=0.178\end{array}$

$68.61 \pm 12.52$

$\begin{array}{ll}\text { Male } & 113(66.5 \%) \\ \text { Female } & 57(33.5 \%) \\ - & p=0.766 \\ \text { Primary cancer diagnosis } & \end{array}$

BC (NSCLC + SCLC, Not applicable primary tumor only)

Head and neck

$47(27.6 \%)$

Rectum or colon

$37(21.8 \%)$

$\mathrm{BC}$ (metastatic dis-

$30(17.6 \%)$

ease)

Malignant melanoma

Esophagus

$13(7.6 \%)$

$9(5.3 \%)$

Sarcoma

$9(5.3 \%)$

Vagina or cervix uteri

$8(4.7 \%)$

CUP

$5(2.9 \%)$

Bladder

$4(2.4 \%)$

Kidney

$4(2.4 \%)$

Breast

$3(1.8 \%)$

MPNST

$1(0.6 \%)$

Histology

Adeno

Squamous

SCLC

$63(37.1 \%)$

$77(45.3 \%)$

$4(2.4)$

BC (no histology or unspecified)

Malignant melanoma

Sarcoma

$1(0.6 \%)$

$13(7.6 \%)$

$9(5.3 \%)$

Kidney spindle cell

MPNST spindle cell

$2(1.2 \%)$

$1(0.6 \%)$

Location in the lung

Upper (right upper + middle and left)

Lower (right and left)

$101(59.4 \%)$

$69(40.6 \%)$

Number of irradiated lung lesions/patient

\begin{tabular}{lll}
1 & $90(52.9 \%)$ & $32(88.9 \%)$ \\
2 & $54(31.8 \%)$ & $4(10.8 \%)$ \\
3 & $18(10.6 \%)$ & - \\
4 & $8(4.7 \%)$ & - \\
Lung metastases & & \\
Metachronous & $163(95.9 \%)$ & Not applicable \\
Synchronous & $7(4.1 \%)$ & - \\
\hline
\end{tabular}

Table 1 (Continued)

\begin{tabular}{|c|c|c|}
\hline \multirow[t]{2}{*}{$\begin{array}{l}\text { General data/medical } \\
\text { history }\end{array}$} & \multirow{2}{*}{$\begin{array}{l}\text { Metastases (MET) } \\
n=170 \text { lesions, } \\
n=124 \text { patients }\end{array}$} & \multirow{2}{*}{$\begin{array}{l}\text { Bronchial carci- } \\
\text { noma (BC) } \\
n=36 \text { lesions, } \\
n=34 \text { patients }\end{array}$} \\
\hline & & \\
\hline \multicolumn{3}{|c|}{$\begin{array}{l}\text { Interval from primary cancer diagnosis to irradiation of metastasis } \\
\text { (months) }\end{array}$} \\
\hline Mean \pm SD & $39.14 \pm 38.92$ & Not applicable \\
\hline Median (range) & $25.28(2.0-225)$ & - \\
\hline \multicolumn{3}{|l|}{ PET-CT prior to irradiation } \\
\hline No & $140(82.4 \%)$ & $18(50.0 \%)$ \\
\hline Yes & $30(17.6 \%)$ & $18(50.0 \%)$ \\
\hline \multicolumn{3}{|c|}{ Other distant metastases at irradiation time point } \\
\hline Yes & $101(59.4 \%)$ & $16(44.4 \%)$ \\
\hline No & $69(40.6 \%)$ & $20(55.6 \%)$ \\
\hline \multicolumn{3}{|c|}{ Concurrent therapy during irradiation } \\
\hline No & $136(80.0 \%)$ & $22(61.1 \%)$ \\
\hline Antibody & $20(11.8 \%)$ & $1(2.8 \%)$ \\
\hline Chemotherapy & $7(4.1 \%)$ & $12(33.3 \%)$ \\
\hline $\begin{array}{l}\text { Tyrosine kinase in- } \\
\text { hibitor }\end{array}$ & $3(1.8 \%)$ & - \\
\hline Chemotherapy + antibody & $3(1.8 \%)$ & $1(2.8 \%)$ \\
\hline $\begin{array}{l}\text { Tyrosine ki- } \\
\text { nase + PARP inhibitor }\end{array}$ & $1(0.6 \%)$ & - \\
\hline \multicolumn{3}{|l|}{ Irradiation } \\
\hline $12 \times 6 \mathrm{~Gy}$ & $170(100 \%)$ & $36(100 \%)$ \\
\hline \multicolumn{3}{|l|}{ PTV total dose (Gy) } \\
\hline Mean \pm SD & $\begin{array}{l}73.01 \pm 1.55 \\
p=0.985\end{array}$ & $73.00 \pm 1.46$ \\
\hline \multirow[t]{2}{*}{ Median (range) } & $\begin{array}{l}72.60 \\
(70.27-76.67)\end{array}$ & $\begin{array}{l}72.81 \\
(71.05-75.27)\end{array}$ \\
\hline & $p=0.798$ & \\
\hline $\operatorname{BED}(\alpha / \beta=10)$ & 116.16 & 116.5 \\
\hline EQD2 & 96.8 & 97.08 \\
\hline \multicolumn{3}{|l|}{ Follow-up time (months) } \\
\hline Mean \pm SD & $\begin{array}{l}22.96 \pm 19.86 \\
p=0.339\end{array}$ & $26.45 \pm 20.65$ \\
\hline \multirow[t]{2}{*}{ Median (range) } & $16.26(0.46-89.34)$ & $\begin{array}{l}19.18 \\
(0.89-91.11)\end{array}$ \\
\hline & $p=0.199$ & \\
\hline \multicolumn{3}{|l|}{ Tumor stage for $B C$} \\
\hline $\mathrm{cT} 1$ & - & $15(41.7 \%)$ \\
\hline $\mathrm{cT} 2$ & - & $12(33.3 \%)$ \\
\hline cT3 & - & $5(13.9 \%)$ \\
\hline cT4 & - & $2(5.6 \%)$ \\
\hline $\begin{array}{l}\text { Missing in the } \\
\text { database }\end{array}$ & - & $2(5.6 \%)$ \\
\hline \multicolumn{3}{|l|}{ Nodal status for $B C$} \\
\hline cNO & - & $22(61.1 \%)$ \\
\hline $\mathrm{cN}+$ & - & $12(33.3 \%)$ \\
\hline $\begin{array}{l}\text { Missing in the } \\
\text { database }\end{array}$ & - & $2(5.6 \%)$ \\
\hline
\end{tabular}
database

Data are number of lesions $(\%)$ unless otherwise stated. $P$-value: analysis of covariance: Mann-Whitney $U$ (median) and Student's t (mean) test, $\chi^{2}$ test in case of categorial data MPNST malignant peripheral nerve sheath tumor 

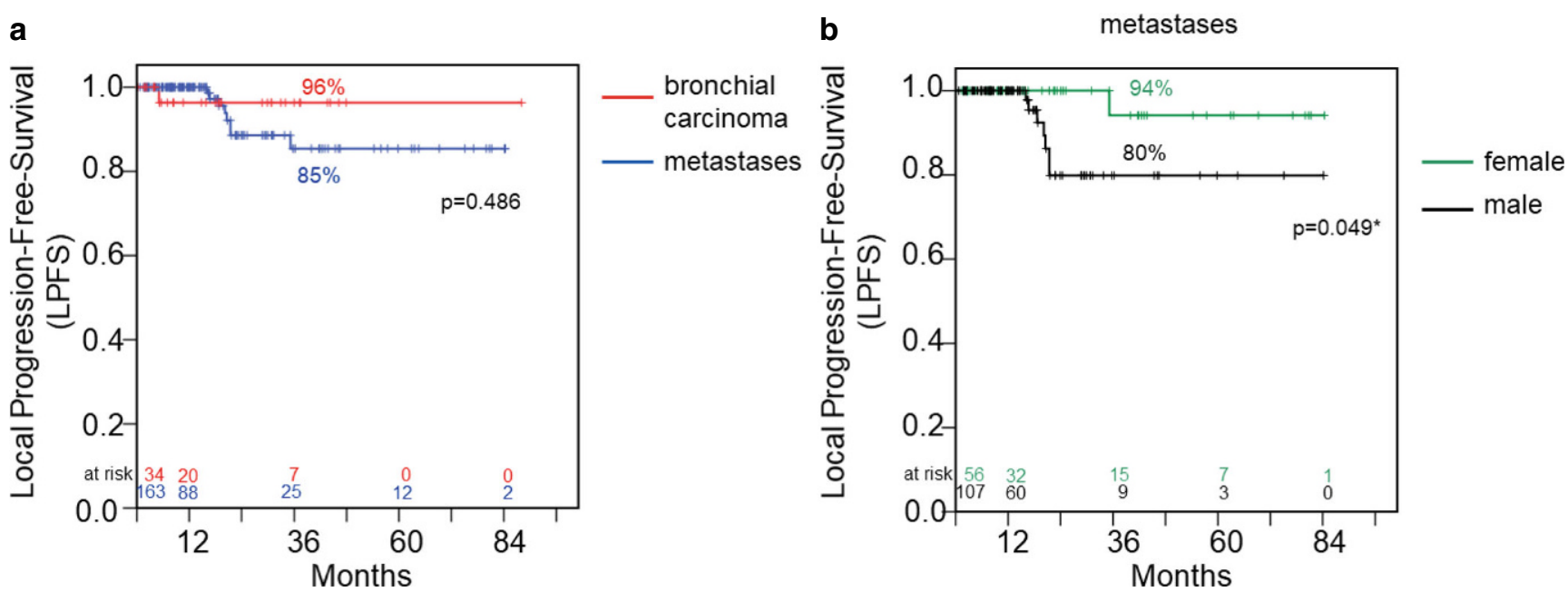

Fig. 3 a Local progression-free survival rates of patients with metastases (blue curve) in relation to patients with primary bronchial carcinoma (red curve) after irradiation. b Local progression-free survival rates of patients with metastases: female gender (green curve) in relation to male gender (black curve) after irradiation. Survival rates are given in $\%$ for 3-year survival (36 months). Significant coherencies $(p<0.05$, log-rank test) are marked with an asterisk

\section{Results}

\section{Patient characteristics}

The baseline characteristics (age, sex, tumor location in the lung, etc.) are listed for MET and BC in Table 1.

The most common primary tumor site for MET patients was head and neck $(27.6 \%, 47$ cases), followed by rectum or colon $(21.8 \%, 37$ cases). Primary bronchial carcinomas were almost always adenocarcinoma (66.7\%, 24 cases), followed by squamous cell carcinoma (13.9\%, 5 cases). For patients with metastatic disease the histology was predominantly squamous carcinoma $(45.3 \%, 77$ cases $)$ or adenocarcinoma $(37.1 \%, 63$ cases). Pulmonary lesions occurred most frequently in the right upper lobe: $30.6 \%$ for metastatic disease vs. $38.9 \%$ for BC. The majority of patients had one or two lesions irradiated with $12 \times 6 \mathrm{~Gy}$ (maximally four, illustrated in Fig. 2).

Tumor stages for primary bronchial carcinoma were: $\leq \mathrm{cT} 1(41.7 \%, 15)$ and $\geq \mathrm{cT} 2(52.8 \%, 19)$. Irradiation was delivered to the PTV in the MET study group to a median total dose of $72.60 \mathrm{~Gy}$ (range: $70.27-76.67 \mathrm{~Gy}$ ) and of $72.81 \mathrm{~Gy}$ (range: $71.05-75.27 \mathrm{~Gy}$ ) in the BC group. The median calculated biological effective dose (BED) was $116.16 \mathrm{~Gy}$ for MET and $116.5 \mathrm{~Gy}$ for BC patients based on $\alpha / \beta=10$. The patients with lymph node or other extrathoracic metastases were sequentially treated with chemoradiation (e.g., mediastinal radiotherapy with boost up to $66 \mathrm{~Gy}$ in case of $\mathrm{N}+$ ) according to the standard of care. Systemic therapy of various regimens was administered concurrently (4 weeks prior and during) with irradiation for $20 \%$ of patients with metastases and $38.9 \%$ of patients with $\mathrm{BC}$.

\section{Survival outcomes and prognostic factors}

The median follow-up at the time of overall survival analysis was 16.26 months (range: 0.46-89.34) for MET and 19.18 months (range: 0.89-91.11) for BC patients. We analyzed the imaging in $163(96 \%)$ of 170 irradiated cases for MET patients and in 34 (94\%) of 36 cases for BC. In a total of 9 cases, the imaging datasets were not available for analyses (Fig. 1).

\section{Local progression-free survival (LPFS)}

LPFS of $96 \%$ for patients with bronchial carcinoma differs not significantly from $85 \%$ for patients with metastases after 3 years (Fig. 3a and Table 2). Detailed information including dose distribution for patients with local progression is presented in Table 3.

A highly relevant beneficial prognostic factor for LPFS (log-rank: $p=0.049$, univariate COX regression analysis: $p=0.036$ ) in patients with metastases was female gender (Fig. 3b). The LPFS rate was for females $94 \%$ after 3 years compared to $80 \%$ for male patients. In bronchial carcinoma patients the gender had no impact on LPFS (log rank: $p=0.228)$.

\section{Progression-free survival (PFS)}

The PFS rate at 3 years for patients with lung metastases was $29 \%$ compared to $35 \%$ for patients with bronchial carcinoma (Online Resource 1). The difference was not significant (log-rank: $p=0.438$, univariate COX regression 0.439, Table 2). 
Table 2 Log-rank survival analysis for patients with metastases compared to patients with primary bronchial carcinoma calculated at 3 years after therapy and univariate analysis according to Cox regression. Significant coherencies $(p<0.05)$ are marked with an asterisk

\begin{tabular}{|c|c|c|c|c|c|}
\hline & \multicolumn{2}{|l|}{ Log-rank } & \multicolumn{3}{|c|}{ Univariate analysis } \\
\hline & $\begin{array}{l}\text { Survival } \\
\text { rate at } \\
3 \text { years }\end{array}$ & $\begin{array}{l}p- \\
\text { value }\end{array}$ & HR & $95 \% \mathrm{CI}$ & $\begin{array}{l}p- \\
\text { value }\end{array}$ \\
\hline \multicolumn{2}{|c|}{$\overline{\text { Overall survival }}$} & 0.823 & 1.056 & $0.656-1.700$ & 0.824 \\
\hline MET & $35 \%$ & & & & \\
\hline $\mathrm{BC}$ & $43 \%$ & & & & \\
\hline \multicolumn{2}{|c|}{$\begin{array}{l}\text { Local progression- } \\
\text { free-survival }\end{array}$} & 0.486 & 0.485 & $0.064-3.885$ & 0.496 \\
\hline MET & $85 \%$ & & & & \\
\hline $\mathrm{BC}$ & $96 \%$ & & & & \\
\hline \multicolumn{2}{|c|}{$\begin{array}{l}\text { Progression-free- } \\
\text { survival }\end{array}$} & 0.438 & 0.804 & $0.462-1.398$ & 0.439 \\
\hline MET & $29 \%$ & & & & \\
\hline $\mathrm{BC}$ & $35 \%$ & & & & \\
\hline
\end{tabular}

\section{Overall survival (OS)}

Overall survival at 3 years was $35 \%$ for MET und $43 \%$ for BC patients (Fig. 4a). There was no statistically significant difference between the groups (Table 2). The non-tumor-related causes of death for 7 patients with metastatic disease were as follows: poor general condition (2), diabetic coma, bronchopulmonary infection, infection of port catheter, cardiac insufficiency, renal insufficiency; and for two bronchial carcinoma patients: poor general condition and chronic ob- structive pulmonary disease. The most common cause of mortality was a systemic progression in both groups.

The presence of systemic progression was a highly relevant prognostic factor for overall survival in the MET group. The Kaplan-Meier analyses showed that the MET patients with no systemic progression had a significantly better $(p=0.048)$ overall survival of $44 \%$ after 3 years compared to patients with systemic progression (OS $28 \%$, Fig. 4b). The multivariate analysis ( $p=0.039$, Table 4$)$ confirms this statement. For BC patients the difference $(60 \%$ versus $31 \%$, diagram not shown) after 3 years was not statistically significant (log-rank $p=0.064$, univariate Cox $p=0.072$, Table 4).

Female gender has a favorable impact on OS for patients with metastases. The OS rate of $60 \%$ for female patients was better than $21 \%$ for male patients (Fig. 4c). The difference was statistically significant in Kaplan-Meier and univariate analysis $(p<0.001)$, but not in multivariate analysis $(p=0.131$, Table 4$)$.

For bronchial carcinoma patients the difference was not significant (57\% female vs. $30 \%$ male, log-rank: OS $p=0.225$, diagram not shown; and univariate analysis $p=0.232$, Table 4).

Furthermore, a significantly better overall survival of $73 \%(p=0.015)$ at 3 years is observed if metastases originated from malignant melanoma compared to other tumor types (up to $40 \%$, Fig. $4 d)$. The univariate Cox $(p=0.012)$ and multivariate Cox analyses $(p=0.020)$ show the same results (Table 4).

Table 3 Characteristics of patients with local progression

\begin{tabular}{|c|c|c|c|c|c|c|c|c|c|c|}
\hline $\begin{array}{l}\text { Patient } \\
\text { no. }\end{array}$ & $\begin{array}{l}\text { Age at } \\
\text { beginning } \\
\text { of RT } \\
\text { (years) }\end{array}$ & Sex & $\begin{array}{l}\text { Primary } \\
\text { tumor } \\
\text { site }\end{array}$ & $\begin{array}{l}\text { Number of } \\
\text { irradiated } \\
\text { pulmonary } \\
\text { lesions }\end{array}$ & $\begin{array}{l}\text { Number of } \\
\text { progressive } \\
\text { pulmonary } \\
\text { lesions }\end{array}$ & Histology & $\begin{array}{l}\text { Location in } \\
\text { the lung }\end{array}$ & $\begin{array}{l}\text { Concurrent } \\
\text { therapy } \\
\text { during } \\
\text { irradiation }\end{array}$ & $\begin{array}{l}\text { Follow- } \\
\text { up time } \\
\text { (months) }\end{array}$ & $\begin{array}{l}\text { Total } \\
\text { dose } \\
\text { (Gy) }\end{array}$ \\
\hline \multicolumn{11}{|c|}{ Pulmonary metastases (all metachronous) } \\
\hline 1 & 65 & Male & Rectum & 2 & 2 & Adeno & $\begin{array}{l}\text { Right mid- } \\
\text { dle } \\
\text { Left upper }\end{array}$ & No & $\begin{array}{l}16.03 \\
16.69\end{array}$ & $\begin{array}{l}72.40 \\
72.00\end{array}$ \\
\hline 2 & 65 & Male & Lung & 2 & 1 & Squamous & $\begin{array}{l}\text { Right } \\
\text { lower }\end{array}$ & No & 20.69 & 72.32 \\
\hline 3 & 70 & Female & $\begin{array}{l}\text { Malignant } \\
\text { melanoma }\end{array}$ & 2 & 1 & $\begin{array}{l}\text { Malignant } \\
\text { melanoma }\end{array}$ & $\begin{array}{l}\text { Right up- } \\
\text { per }\end{array}$ & No & 33.15 & 68.30 \\
\hline 4 & 73 & Male & Colon & 1 & 1 & Adeno & Left lower & No & 18.62 & 72.20 \\
\hline \multirow[t]{2}{*}{5} & 57 & Male & Esophagus & 3 & 3 & Squamous & $\begin{array}{l}\text { Right } \\
\text { lower } \\
\text { Left lower } \\
\text { Left lower }\end{array}$ & No & $\begin{array}{l}20.56 \\
21.41 \\
21.41\end{array}$ & $\begin{array}{l}71.86 \\
72.21 \\
72.55\end{array}$ \\
\hline & & & & & & & & & & $\begin{array}{l}\text { Median } \\
\mathbf{7 2 . 2 0}\end{array}$ \\
\hline \multicolumn{11}{|c|}{ Primary bronchial carcinoma } \\
\hline 6 & 85 & Female & Lung & 1 & 1 & Adeno & $\begin{array}{l}\text { Right up- } \\
\text { per }\end{array}$ & No & 5.08 & 71.44 \\
\hline- & - & - & - & - & Total 9 & - & - & - & - & - \\
\hline
\end{tabular}


a
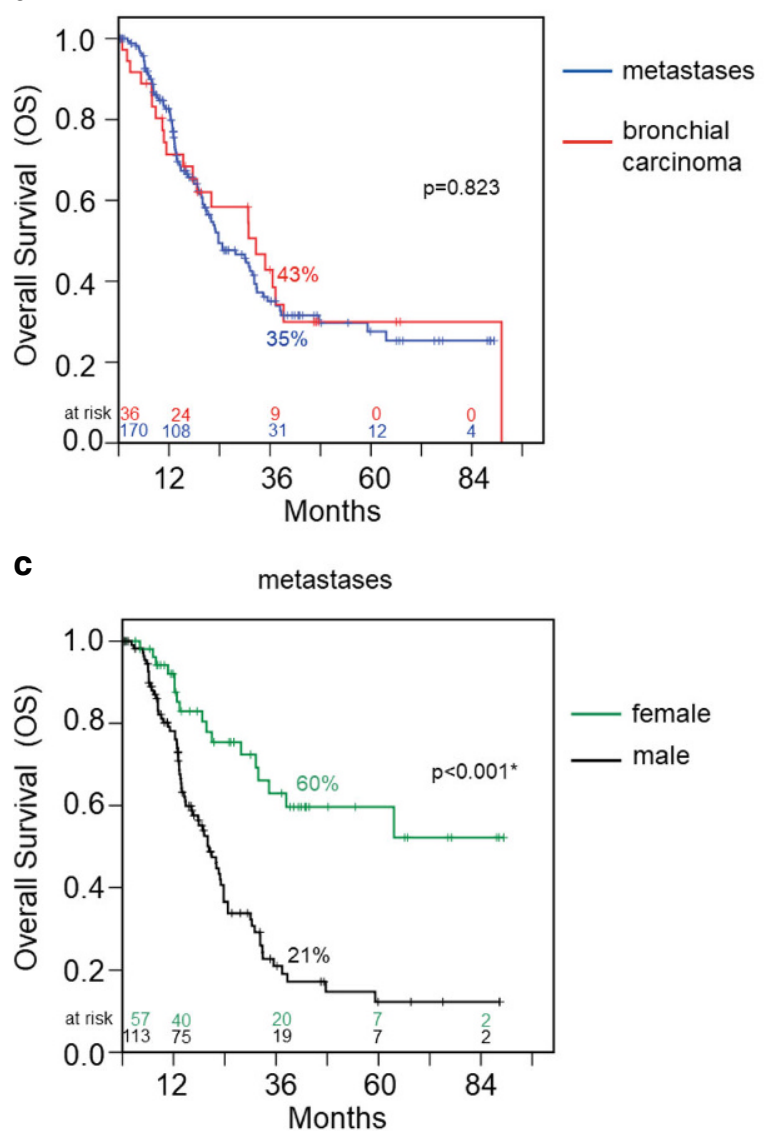

e Bronchial carcinoma

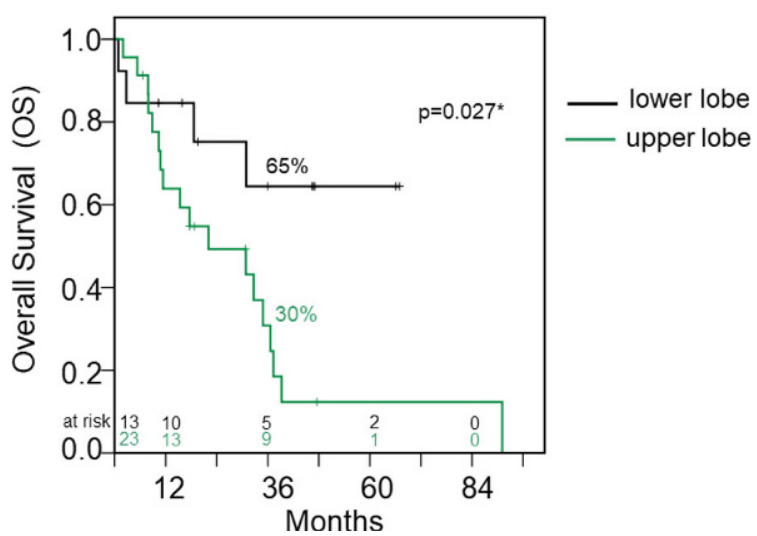

b

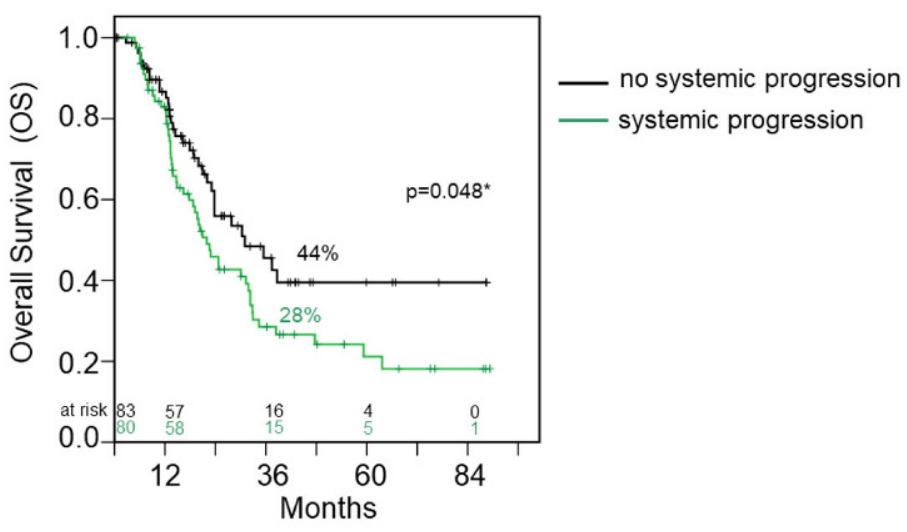

d

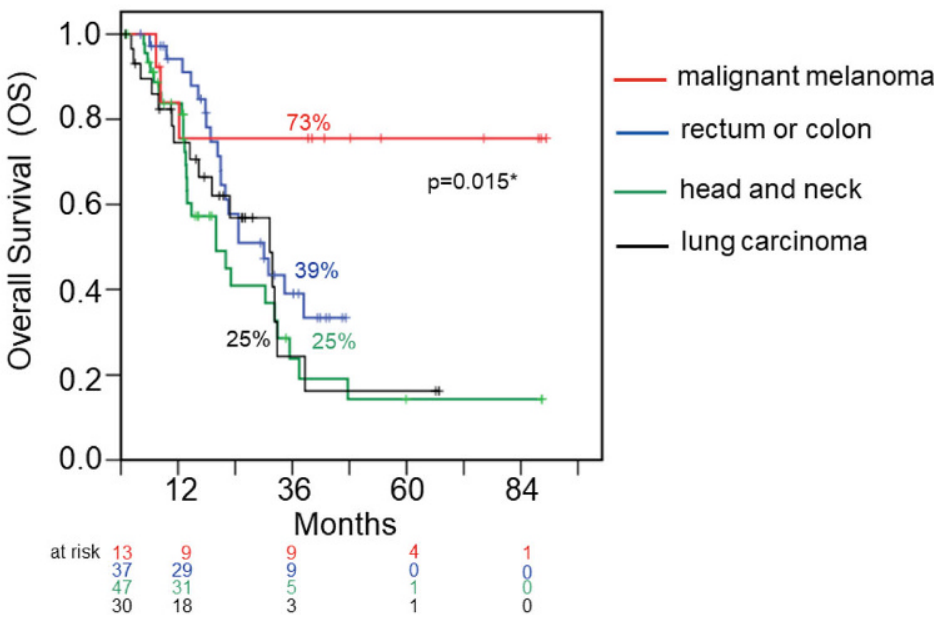

Fig. 4 a Overall survival rates of patients with metastases (blue curve) in relation to patients with primary bronchial carcinoma (red curve) after irradiation. b Overall survival rates of patients with metastases. Impact of systemic progression: patients with no systemic progression (black curve) in relation to systemic progression (green curve) after irradiation. c Overall survival rates of patients with metastases. Gender: female (green curve) in relation to male (black curve) after irradiation. d Overall survival rates of patients with metastases. Primary tumor site: malignant melanoma (red curve) in relation to rectum or colon (blue curve), head and neck (green curve), and lung carcinoma (black curve) after irradiation. e Overall survival rates of patients with bronchial carcinoma. Tumor location: lower lobe (black curve) in relation to upper lobe (green curve) after irradiation. Survival rates are given in \% for 3-year survival (36 months). Significant coherencies $(p<0.05, \log$-rank test) were marked with an asterisk 
Table 4 Univariate (MET and BC) and multivariate analysis (MET only) of the influence of patient- and therapy-related parameters to overall survival for patients treated with $12 \times 6$ Gy. Significant coherencies $(p<0.05)$ were marked with an asterisk. Hazard ratios and $95 \%$ confidence interval

\begin{tabular}{|c|c|c|c|c|c|c|c|c|c|c|}
\hline \multirow[b]{3}{*}{ Variables } & \multirow[b]{3}{*}{ Category } & \multicolumn{6}{|c|}{ Metastases } & \multirow{2}{*}{\multicolumn{3}{|c|}{$\begin{array}{l}\text { Bronchial carcinoma } \\
\text { Univariate } \\
\end{array}$}} \\
\hline & & \multicolumn{3}{|c|}{ Univariate } & \multicolumn{3}{|c|}{ Multivariate } & & & \\
\hline & & $\overline{\mathrm{HR}}$ & $95 \% \mathrm{CI}$ & $p$-value & HR & $95 \% \mathrm{CI}$ & $p$-value & HR & $95 \% \mathrm{CI}$ & p-value \\
\hline Sex & $\begin{array}{l}\text { Female vs. } \\
\text { male }\end{array}$ & 0.311 & $0.182-0.531$ & $<0.001 *$ & 0.529 & $0.232-1.208$ & 0.131 & 0.560 & $0.217-1.448$ & 0.232 \\
\hline $\begin{array}{l}\text { Systemic progres- } \\
\text { sion }\end{array}$ & Yes vs. no & 0.647 & $0.418-1.001$ & $0.051 *$ & 0.423 & $0.188-0.956$ & $0.039 *$ & 0.425 & $0.167-1.081$ & 0.072 \\
\hline Primary tumor site & $\begin{array}{l}\text { Malignant } \\
\text { melanoma vs. } \\
\text { other }\end{array}$ & 0.224 & $0.069-0.723$ & $0.012 *$ & 0.009 & $0.000-0.478$ & $0.020 *$ & \multicolumn{3}{|c|}{ Not applicable } \\
\hline Histology & $\begin{array}{l}\text { Adeno vs. } \\
\text { squamous }\end{array}$ & 0.688 & $0.435-1.088$ & 0.110 & 0.816 & $0.343-1.943$ & 0.646 & 1.954 & $0.438-8.714$ & 0.380 \\
\hline $\begin{array}{l}\text { Age at beginning } \\
\text { of RT }\end{array}$ & Years & 1.011 & $0.990-1.031$ & 0.308 & \multicolumn{3}{|c|}{ Not possible } & 1.002 & $0.966-1.039$ & 0.923 \\
\hline $\begin{array}{l}\text { Location in the } \\
\text { lung }\end{array}$ & $\begin{array}{l}\text { Upper vs. } \\
\text { lower }\end{array}$ & 1.467 & $0.964-2.231$ & 0.074 & 1.087 & $0.566-2.089$ & 0.802 & 0.310 & $0.103-0.929$ & $0.036^{*}$ \\
\hline $\begin{array}{l}\text { Number of irradi- } \\
\text { ated lung lesions/ } \\
\text { patient }\end{array}$ & $1+2$ vs. $3+4$ & 0.777 & $0.457-1.321$ & 0.352 & \multicolumn{3}{|c|}{ Not possible } & \multicolumn{3}{|c|}{ Not possible } \\
\hline $\begin{array}{l}\text { Other distant } \\
\text { metastases at irra- } \\
\text { diation timepoint }\end{array}$ & Yes vs. no & 1.220 & $0.802-1.858$ & 0.353 & \multicolumn{3}{|c|}{ Not possible } & 0.530 & $0.637-3.675$ & 0.342 \\
\hline $\begin{array}{l}\text { Concurrent ther- } \\
\text { apy during irradia- } \\
\text { tion }\end{array}$ & Yes vs. no & 1.115 & $0.637-1.950$ & 0.704 & \multicolumn{3}{|c|}{ Not possible } & 0.498 & $0.200-1.243$ & 0.135 \\
\hline $\begin{array}{l}\text { PET-CT prior to } \\
\text { irradiation }\end{array}$ & Yes vs. no & 0.976 & $0.527-1.809$ & 0.940 & \multicolumn{3}{|c|}{ Not possible } & 1.476 & $0.610-3.570$ & 0.388 \\
\hline Local progression & Yes vs. no & 0.800 & $0.367-1.743$ & 0.547 & \multirow{2}{*}{\multicolumn{3}{|c|}{ Not possible }} & 0.169 & $0.20-1.452$ & 0.105 \\
\hline $\begin{array}{l}\text { Tumor stage for } \\
\text { BC }\end{array}$ & T1 vs. T2-T4 & \multicolumn{3}{|c|}{ Not applicable } & & & & 0.396 & $0.150-1.045$ & 0.061 \\
\hline $\begin{array}{l}\text { Nodal status for } \\
\text { BC }\end{array}$ & N0 vs. N+ & \multicolumn{6}{|c|}{ Not applicable } & 1.859 & $0.723-4.780$ & 0.198 \\
\hline
\end{tabular}

The "tumor location" variable showed a benefit in OS in the $\mathrm{BC}$ group. We compared the tumor location within the upper (right and left) including middle lobe to a location within the lower lobe (right and left). After 3 years the overall survival rate of $65 \%$ for patients with a "lower lobe" location was significantly better (log-rank: $p=0.027$, univariate COX analysis $p=0.036$ ) compared to $30 \%$ for an "upper lobe" location (Fig. 4e; Table 4).

The group of patients with metastatic disease showed a contrasting pattern. Patients with lesions within the upper lobe showed an overall survival of $40 \%$ compared to the patients with a tumor location in the lower lobe at $26 \%$ (diagram not shown). The difference was not significant ( $p=0.071 \mathrm{log}$ rank, $p=0.074$ univariate analysis).

For bronchial carcinoma patients, tumor stage $\leq \mathrm{T} 1$ show a trend $(p=0.053)$ for better overall survival at 3 years $(57 \%$ $\leq \mathrm{T} 1$ compared to $35 \% \geq \mathrm{T} 2$; Online Resource 2; Table 4).

\section{Adverse events (AE)}

The overall incidence of AEs suspected to be related to the irradiation was low. There were no interruptions of irradiation due to toxicity. No deaths occurred during irradiation or due to irradiation. Four patients mentioned in the Survival outcomes and prognostic factors section (as without imaging) died immediately after irradiation due to primary head and neck tumor bleeding (one MET patient), toxicity in consequence of concurrent chemotherapy (one BC patient), and serious infection (one BC und one MET patient). No heart toxicity, lung bleeding, esophagitis, or dysphagia were observed. The most frequently observed grade $3 \mathrm{AE}$ was pneumonitis for both groups $(5.9 \% \mathrm{BC}, 4.8 \% \mathrm{MET})$, followed by pulmonary fibrosis $(2.9 \% \mathrm{BC}, 4 \% \mathrm{MET})$ and pulmonary embolism $(2.9 \% \mathrm{BC}, 0.8 \% \mathrm{MET})$. We observed five rib fractures in 3 patients (8.8\%) with $\mathrm{BC}$ and 2 patients $(1.6 \%) \mathrm{w}$ metastatic disease. 


\section{Discussion}

This study compared the safety and long-term survival outcomes after a stereotactic radiotherapy with $12 \times 6 \mathrm{~Gy}$ for patients with primary bronchial carcinoma and patients with lung metastases of various solid tumors. We have identified prognostic factors that may influence local progressionfree-survival (LPFS) and overall survival.

From our results, female gender, absence of systemic progression, and malignant melanoma histology for MET patients, and tumor location within the lower lobe or tumor stage $\geq \mathrm{T} 1$ for $\mathrm{BC}$ patients were favorable prognostic factors.

The major efficacy outcome measure of the trial was local progression-free survival. 3-year outcome data showed 96\% LPFS for lung carcinoma patients and $83 \%$ for MET patients. Our LPFS rate of $83 \%$ for patients with lung metastases was comparable with $81.3 \%$ (3 years) in one of the largest multicenter (68 centers) analyses consisting of 1547 cases by Yamamoto et al. [16], and lower compared to $94.1 \%$ or $89 \%$ as seen in retrospective series consisting of 129 cases by Borm et al. [8] or 61 cases by Ricardi et al. [17], respectively. The treatment schedules contained 3-7 fractions up to a biologically equivalent dose $\left(\mathrm{BED}_{10}\right)$ of 75.0-289.5 Gy (median 105.6 Gy) [16]. The patients in the analysis of Borm et al. and Ricardi et al. were treated with a total dose that ranged between 14 and $45 \mathrm{~Gy}$, given mainly in 3 or 5 fractions [8], or 1-4 fractions [17]. Our local failure rate for BC patients of $4 \%$ after 3 years was considerably lower compared to 2-year rates of $38.6 \%$ or $29 \%$ reported by Bradley et al. [18] and McDermott et al. [19], respectively.

With the excellent local control, no uniform pattern of failure is clearly identifiable in our study. In 8 of $163(5 \%)$ of MET and in one (3\%) of 34 of BC lesions, we observed local progression. Various dose fractionation schedules are reported for lung lesions in the literature, varying between 1 and 10 fractions; however, the optimal dose remains unknown and a comparison of outcomes challenging. The schedules with a biologically equivalent dose $\left(\mathrm{BED}_{10}\right)$ of $100 \mathrm{~Gy}$ or more are associated with high local disease control rates [20-22]. We recorded no difference in radiotherapy delivery between the investigated groups. Except for the above mentioned malignant melanoma patient, we administered the recommended dose (in median of $72.20 \mathrm{~Gy}$, $\mathrm{BED}_{10}$ 115.52) to the target volume, even for patients with local progression.

Female gender was the only independently significant highly beneficial prognostic factor for LPFS of patients with metastatic disease, but not for bronchial carcinoma. Klement et al. evaluated a radiobiological model for long-term prediction of tumor control probability (TCP) for stereotactic irradiation of pulmonary metastases. The female sex was associated with higher control probability [23]. Rodrigues et al. reported in contrast that LPFS was negatively influenced by female gender after SBRT for early-stage inoperable primary lung tumors [24]. No other factors were found to have an impact on local LPFS, probably due to, fortunately, very high response rates.

Much effort has been focused on the ability of SRT to control tumors locally, but the risk of distant metastasis remains a major issue for both patient groups. During followup, the life expectancy of the patients in the herein presented study was predominantly limited by systemic progression. A PFS rate of $29 \%$ at 3 years for patients with lung metastases differs non-significantly from $35 \%$ for patients with bronchial carcinoma. In terms of the incidence of metastases in $\mathrm{BC}$, our results appear to be quite different to results of the RTOG 0236 trial, with $48 \%$ diseasefree survival 3 years after irradiation [25], or an analysis of Abdalmassih et al. (2020) with 51\% at 2 years [26]. It is generally difficult to compare progression-free survival due to heterogeneous inclusion criteria, especially the number of other distant metastases and variety of irradiation treatments. In our series we did not recognize any independent prognostic factors for PFS.

Successful local therapy for lung lesions, regardless of whether primary or metastatic, may lead to longer survival. We observed no difference in overall survival after 3 years between the groups (35\% for MET vs. $43 \%$ for BC). The OS rate of $35 \%$ for patients with irradiated metastases was lower in our study than the average values (range $38-84.3 \%$ ) of previous studies [8, 17, 27-31]. We agree here with the opinion of previous reports that the careful selection of patients (e.g., no other extrathoracic metastases) for analysis [17, 27, 32] positively influenced the overall survival. Clinical outcomes after SRT for inoperable NSCLC vary significantly between different studies: 3 -year overall survival (OS) ranges from $37 \%$ to $72 \%$ [25, $33,34]$. In our series, the OS rate for patients with primary BC after 3 years was $43 \%$. Only a minority of reports on SRT have a long follow-up [6]. Therefore, these results should be interpreted with caution, since SRT is currently still reserved for patients unfit or unwilling to undergo surgical treatment and this might have a considerable impact on the survival rates.

Previous studies confirmed that no new metastases during follow-up [28] and a long event-free interval [35, 36] are beneficial prognostic factors for overall survival of patients with metastases. MET patients in our study with "no systemic progression" have a significantly better overall survival of $44 \%$ after 3 years compared to patients with systemic progression (OS 28\%). For BC patients we observed no difference.

A highly beneficial prognostic factor for patients with metastases but not for patients with primary lung cancer was 
female gender (MET 3-year OS: $60 \%$ vs. $21 \%, p<0.001$ ). De Vin et al. showed the same scope [37]. Little is known about the impact of gender for MET patients after SRT. On the other hand, a retrospective analysis of 243 patients from the Japanese Lung Cancer Registry suggested that gender is one of the independent prognostic factors for lung carcinoma [38, 39]. For early-stage inoperable NSCLC, when compared to men 2 years after SRT, women had a statistically superior OS of $75 \%$ compared to $52 \%$ for men [26]. In a patient cohort with limited-disease SCLC, female gender was significantly associated with longer OS [38, 40].

Various types of cancer show significant differences in tumor response after SRT. Some authors described that better local control was observed if metastases did not originate from the colon [41-44] and local failure of irradiated metastases of colon carcinoma has been reported to have a correlation with worse overall survival [45]. Our analysis regarding the impact of local control could not confirm this statement, but when comparing our results for metastases from various tumors, we found that malignant melanoma histology had a highly relevant impact on overall survival against other tumor types. Malignant melanoma patients responded better (OS 73\%) compared to other tumor types (OS 25-39\%) after 3 years.

We asked ourselves: Why was the overall survival of malignant melanoma patients better compared to patients with other histologies? Additional administration of pembrolizumab had an impact on overall survival in our analysis. We irradiated 13 lesions from 8 patients. One patient had local progression (Table 2). Almost all of our malignant melanoma patients were treated successfully with pembrolizumab after irradiation (but not prior to) for a longer period of time. Only one female patient did not respond and died. Since the publication of the KEYNOTE-001 study, it has been known that pembrolizumab demonstrates robust antitumor activity [46].

The factor "tumor location in the lung" was a highly relevant ( $p=0.027$ log-rank, Cox: univariate analysis $p=0.036$ ) prognostic factor for OS in patients with primary lung cancer. Patients with lesions within the lower lobe responded better (OS 65\% after 3 years) compared to patients with lesions in the upper lobe (OS 30\%). For patients with metastases, it is exactly the opposite, but non-significant. In the literature review of 20 publications reporting outcomes for lung tumors treated with stereotactic radiotherapy, tumor location in the lung did not appear to impact OS, but did impact toxicity [5]. As might be expected, grade 3 and 4 toxicities were more prevalent for central tumors [5, 47]. With respect to our small sample size and heterogenous patient population including $\mathrm{N}+$ and $\mathrm{M} 1$ patients, we found that overall survival of bronchial carcinoma patients was influenced by tumor stage. The patients with $\geq \mathrm{T} 1$ tumors (OS 57\%) showed a trend toward better overall survival than the patients with $\geq \mathrm{T} 2$ tumors (OS 35\%). Rodrigues at al. showed that $\mathrm{T} 2$ tumors were associated with lower local control rates than $\mathrm{T} 1$, with no significant impact on overall survival [24]. Other factors that were evaluated during statistical analysis, included age, number of irradiated lesions in the lung, presence of other distant metastases at the irradiation timepoint, application of a concurrent systemic therapy regimen, PET-CT diagnostics prior to irradiation, and the presence of local progression, were all found to be non-statistically significant for LPFS, PFS, and OS.

Using higher doses in stereotactic radiotherapy is a clinical decision in which tumor control is weighed against toxicity. Unfortunately, the higher biologically equivalent doses (BED) can also result in toxicity. The $12 \times 6 \mathrm{~Gy}\left(\mathrm{BED}_{10}\right.$ $116 \mathrm{~Gy}$ ) stereotactic radiotherapy was generally well tolerated, which is reflected in compliance. In the majority of studies that reported adverse events these were grade 1 and grade 2 toxicity, without the need for further treatments [8, 27, 31]. In our analysis, the overall incidence of AEs suspected to be related to the irradiation was low and showed no clinical correlate in most cases. Our findings are in accordance with previous studies that described high-grade $(\geq 3)$ adverse events to be well under $10 \%[8,17,27-32$, $35,48]$.

The strengths of our findings are a homogeneous and safe radiotherapy concept with $12 \times 6 \mathrm{~Gy}$, the large series of 206 cases, and the long follow-up period. Nevertheless, identifying patients who are most likely to benefit from stereotactic therapy is probably the most significant challenge, as well as obtaining high quality prospective data. Furthermore, there is still a need for prospective studies with clearly defined inclusion criteria with a focus on the presence of extrathoracic metastases of lung lesions, including primary lung cancer and metastases of solid tumors.

\section{Conclusion}

The treatment concept of $12 \times 6 \mathrm{~Gy}$ might be safe and was associated with $96 \%$ local progression-free survival for BC and $85 \%$ for pulmonary metastases after 3 years. The most common cause of failure was systemic progression in both groups. Primary bronchial carcinoma responded similarly to lung metastases of various solid tumors.

Supplementary Information The online version of this article (https:// doi.org/10.1007/s00066-021-01811-3) contains supplementary material, which is available to authorized users.

Acknowledgements We thank Ms. Tatjana Einwag from the Clinical Cancer Registry, Comprehensive Cancer Center Erlangen-EMN, University Hospital Erlangen, Germany for providing the demographic data. 
Funding Open Access funding enabled and organized by Projekt DEAL.

\section{Declarations}

Conflict of interest D. Lubgan, S. Semrau, U. Lambrecht, U.S. Gaipl, and R. Fietkau declare that they have no competing interests.

Ethical standards All procedures performed in studies involving human participants or on human tissue were in accordance with the ethical standards of the institutional and/or national research committee and with the 1975 Helsinki declaration and its later amendments or comparable ethical standards. Informed consent was obtained from all individual participants included in the study.

Open Access This article is licensed under a Creative Commons Attribution 4.0 International License, which permits use, sharing, adaptation, distribution and reproduction in any medium or format, as long as you give appropriate credit to the original author(s) and the source, provide a link to the Creative Commons licence, and indicate if changes were made. The images or other third party material in this article are included in the article's Creative Commons licence, unless indicated otherwise in a credit line to the material. If material is not included in the article's Creative Commons licence and your intended use is not permitted by statutory regulation or exceeds the permitted use, you will need to obtain permission directly from the copyright holder. To view a copy of this licence, visit http://creativecommons.org/licenses/by/4. $0 /$.

\section{References}

1. Budczies $\mathrm{J}$, von Winterfeld $\mathrm{M}$, Klauschen $\mathrm{F}$, Bockmayr $\mathrm{M}$, Lennerz JK, Denkert C, Wolf T, Warth A, Dietel M, Anagnostopoulos I, Weichert W, Wittschieber D, Stenzinger A (2015) The landscape of metastatic progression patterns across major human cancers. Oncotarget 6(1):570-583. https://doi.org/10.18632/ oncotarget. 2677

2. Suzuki S, Goto T (2020) Role of surgical intervention in unresectable non-small cell lung cancer. J Clin Med. https://doi.org/10. 3390/jcm9123881

3. Cheung F, Alam N, Wright G (2018) Pulmonary metastasectomy: analysis of survival and prognostic factors in 243 patients. ANZ J Surg 88(12):1316-1321. https://doi.org/10.1111/ans.14811

4. Khorfan R, Kruser TJ, Coughlin JM, Bharat A, Bilimoria KY, Odell DD (2020) Survival of primary stereotactic body radiation therapy compared with surgery for operable stage I/II non-small cell lung cancer. Ann Thorac Surg 110(1):228-234. https://doi.org/ 10.1016/j.athoracsur.2020.01.073

5. Prezzano KM, Ma SJ, Hermann GM, Rivers CI, Gomez-Suescun JA, Singh AK (2019) Stereotactic body radiation therapy for non-small cell lung cancer: a review. World J Clin Oncol 10(1):14-27. https://doi.org/10.5306/wjco.v10.i1.14

6. Londero F, Grossi W, Morelli A, Parise O, Masullo G, Tetta C, Livi U, Maessen JG, Gelsomino S (2020) Surgery versus stereotactic radiotherapy for treatment of pulmonary metastases. A systematic review of literature. Future Sci OA 6(5):FSO471. https:// doi.org/10.2144/fsoa-2019-0120

7. Rieber J, Streblow J, Uhlmann L, Flentje M, Duma M, Ernst I, Blanck O, Wittig A, Boda-Heggemann J, Krempien R, Lohaus F, Klass ND, Eble MJ, Imhoff D, Kahl H, Petersen C, Gerum S, Henkenberens C, Adebahr S, Hass P, Schrade E, Wendt TG, Hildebrandt G, Andratschke N, Sterzing F, Guckenberger M (2016) Stereotactic body radiotherapy (SBRT) for medically inoperable lung metastases - a pooled analysis of the German working group “stereotactic radiotherapy". Cancer Treat Res 97:51-58. https://doi. org/10.1016/j.lungcan.2016.04.012

8. Borm KJ, Oechsner M, Schiller K, Peeken JC, Dapper H, Munch S, Kroll L, Combs SE, Duma MN (2018) Prognostic factors in stereotactic body radiotherapy of lung metastases. Strahlenther Onkol 194(10):886-893. https://doi.org/10.1007/s00066-018-1335-x

9. World Medical Association (2013) World medical association declaration of helsinki: ethical principles for medical research involving human subjects. JAMA 310(20):2191-2194. https://doi.org/10. 1001/jama.2013.281053

10. EMA (1996) ICH topic E3, note for guidance on structure and content of clinical study reports (CPMP/ICH/137/95)

11. Eisenhauer EA, Therasse P, Bogaerts J, Schwartz LH, Sargent D, Ford R, Dancey J, Arbuck S, Gwyther S, Mooney M, Rubinstein L, Shankar L, Dodd L, Kaplan R, Lacombe D, Verweij J (2009) New response evaluation criteria in solid tumours: revised RECIST guideline (version 1.1). Eur J Cancer 45(2):228-247. https://doi. org/10.1016/j.ejca.2008.10.026

12. Kirch W (2008) Pearson's correlation coefficient. In: Kirch W (ed) Encyclopedia of public health. Springer Netherlands, Dordrecht, pp 1090-1091 https://doi.org/10.1007/978-1-4020-5614-7_2569

13. Kaplan EL, Meier P (1958) Non-parametric estimation from incomplete observations. J Am Stat Assoc 53:457-481

14. Mantel N (1966) Evaluation of survival data and two new rank order statistics arising in its consideration. Cancer Chemother Rep 50(3): 163-170

15. Cox DR (1972) Non-parametric estimation from incomplete observations. J R Stat Soc Series B Stat Methodol 34:187-202

16. Yamamoto T, Niibe Y, Aoki M, Shintani T, Yamada K, Kobayashi M, Yamashita H, Ozaki M, Manabe Y, Onishi H, Yahara K, Nishikawa A, Katsui K, Oh RJ, Terahara A, Jingu K (2020) Analyses of the local control of pulmonary oligometastases after stereotactic body radiotherapy and the impact of local control on survival. BMC Cancer 20(1):997. https://doi.org/10.1186/s12885-020-07514-9

17. Ricardi U, Filippi AR, Guarneri A, Ragona R, Mantovani C, Giglioli F, Botticella A, Ciammella P, Iftode C, Buffoni L, Ruffini E, Scagliotti GV (2012) Stereotactic body radiation therapy for lung metastases. Cancer Treat Res 75(1):77-81. https://doi.org/10.1016/ j.lungcan.2011.04.021

18. Bradley JD, Paulus R, Komaki R, Masters G, Blumenschein G, Schild S, Bogart J, Hu C, Forster K, Magliocco A, Kavadi V, Garces YI, Narayan S, Iyengar P, Robinson C, Wynn RB, Koprowski C, Meng J, Beitler J, Gaur R, Curran W Jr., Choy H (2015) Standard-dose versus high-dose conformal radiotherapy with concurrent and consolidation carboplatin plus paclitaxel with or without cetuximab for patients with stage IIIA or IIIB nonsmall-cell lung cancer (RTOG 0617): a randomised, two-by-two factorial phase 3 study. Lancet Oncol 16(2):187-199. https://doi. org/10.1016/S1470-2045(14)71207-0

19. McDermott RL, Mihai A, Dunne M, Keys M, O’Sullivan S, Thirion P, ElBeltagi N, Armstrong JG (2020) Stereotactic ablative radiation therapy for large (\rangle$/=5 \mathrm{~cm})$ non-small cell lung carcinoma. Clin Oncol (R Coll Radiol). https://doi.org/10.1016/j. clon.2020.11.026

20. McDonald F, De Waele M, Hendriks LE, Faivre-Finn C, Dingemans AC, Van Schil PE (2017) Management of stage I and II nonsmall cell lung cancer. Eur Respir J. https://doi.org/10.1183/ 13993003.00764-2016

21. Olsen JR, Robinson CG, El Naqa I, Creach KM, Drzymala RE, Bloch C, Parikh PJ, Bradley JD (2011) Dose-response for stereotactic body radiotherapy in early-stage non-small-cell lung cancer. Int J Radiat Oncol Biol Phys 81(4):e299-303. https://doi.org/10. 1016/j.ijrobp.2011.01.038

22. Onishi H, Shirato H, Nagata Y, Hiraoka M, Fujino M, Gomi K, Niibe Y, Karasawa K, Hayakawa K, Takai Y, Kimura T, Takeda A, Ouchi A, Hareyama M, Kokubo M, Hara R, Itami J, Yamada K, 
Araki T (2007) Hypofractionated stereotactic radiotherapy (HypoFXSRT) for stage I non-small cell lung cancer: updated results of 257 patients in a Japanese multi-institutional study. J Thorac Oncol 2(7):S94-100. https://doi.org/10.1097/JTO.0b013e318074d e34

23. Klement RJ, Allgauer M, Andratschke N, Blanck O, Boda-Heggemann J, Dieckmann K, Duma M, Ernst I, Flentje M, Ganswindt U, Hass P, Henkenberens C, Imhoff D, Kahl HK, Krempien R, Lohaus F, Nestle U, Nevinny-Stickel M, Petersen C, Schmitt V, Semrau S, Sterzing F, Streblow J, Wendt TG, Wittig A, Guckenberger M (2016) Bayesian cure rate modeling of local tumor control: evaluation in stereotactic body radiation therapy for pulmonary metastases. Int J Radiat Oncol Biol Phys 94(4):841-849. https://doi.org/ 10.1016/j.ijrobp.2015.12.004

24. Rodrigues I, Figueiredo T, Gagean J, Ferreira C, Laranja A, Ramos T, Conde S, Moreira D, Cardia J (2020) Prognostic factors and clinical outcomes after stereotactic radiotherapy for primary lung tumors. Rep Pract Oncol Radiother 25(6):943-950. https:// doi.org/10.1016/j.rpor.2020.09.015

25. Timmerman RD, Hu C, Michalski JM, Bradley JC, Galvin J, Johnstone DW, Choy H (2018) Long-term results of stereotactic body radiation therapy in medically inoperable stage I non-small cell lung cancer. JAMA Oncol 4(9):1287-1288. https://doi.org/10.1001/ jamaoncol.2018.1258

26. Abdalmassih M, Bucher O, Rathod S, Dubey A, Kim JO, Ahmed N, Leylek A, Chowdhury A, Bashir B (2020) Clinical outcomes after stereotactic body radiation therapy for early stage non-small cell lung cancer: a single institutional study. Cureus 12(12):e11886. https://doi.org/10.7759/cureus.11886

27. De Rose F, Cozzi L, Navarria P, Ascolese AM, Clerici E, Infante M, Alloisio M, Testori A, Toschi L, Finocchiaro G, Santoro A, Scorsetti M (2016) Clinical outcome of stereotactic ablative body radiotherapy for lung metastatic lesions in non-small cell lung cancer oligometastatic patients. Clin Oncol (R Coll Radiol) 28(1):13-20. https://doi.org/10.1016/j.clon.2015.08.011

28. Hof H, Hoess A, Oetzel D, Debus J, Herfarth K (2007) Stereotactic single-dose radiotherapy of lung metastases. Strahlenther Onkol 183(12):673-678. https://doi.org/10.1007/s00066-007-1724-z

29. Inoue T, Oh RJ, Shiomi H, Masai N, Miura H (2013) Stereotactic body radiotherapy for pulmonary metastases. Prognostic factors and adverse respiratory events. Strahlenther Onkol 189(4):285-292. https://doi.org/10.1007/s00066-012-0290-1

30. Nuyttens JJ, van der Voort van Zyp NC, Verhoef C, Maat A, van Klaveren RJ, van der Holt B, Aerts J, Hoogeman M (2015) Stereotactic body radiation therapy for oligometastases to the lung: a phase 2 study. Int J Radiat Oncol Biol Phys 91(2):337-343. https://doi.org/10.1016/j.ijrobp.2014.10.021

31. Rusthoven KE, Kavanagh BD, Burri SH, Chen C, Cardenes H, Chidel MA, Pugh TJ, Kane M, Gaspar LE, Schefter TE (2009) Multi-institutional phase I/II trial of stereotactic body radiation therapy for lung metastases. J Clin Oncol 27(10):1579-1584. https://doi.org/10.1200/JCO.2008.19.6386

32. Navarria P, Ascolese AM, Tomatis S, Cozzi L, De Rose F, Mancosu P, Alongi F, Clerici E, Lobefalo F, Tozzi A, Reggiori G, Fogliata A, Scorsetti M (2014) Stereotactic body radiotherapy (sbrt) in lung oligometastatic patients: role of local treatments. Radiat Oncol 9(1):91. https://doi.org/10.1186/1748-717X-9-91

33. Kang J, Ning MS, Feng H, Li H, Bahig H, Brooks ED, Welsh JW, Ye R, Miao H, Chang JY (2020) Predicting 5-year progression and survival outcomes for early stage non-small cell lung cancer treated with stereotactic ablative radiation therapy: development and validation of robust prognostic nomograms. Int J Radiat Oncol Biol Phys 106(1):90-99. https://doi.org/10.1016/j.ijrobp.2019.09.037

34. Onishi H, Araki T, Shirato H, Nagata Y, Hiraoka M, Gomi K, Yamashita T, Niibe Y, Karasawa K, Hayakawa K, Takai Y, Kimura T, Hirokawa Y, Takeda A, Ouchi A, Hareyama M, Kokubo M, Hara R,
Itami J, Yamada K (2004) Stereotactic hypofractionated high-dose irradiation for stage I nonsmall cell lung carcinoma: clinical outcomes in 245 subjects in a Japanese multiinstitutional study. Cancer 101(7):1623-1631. https://doi.org/10.1002/cncr.20539

35. Norihisa Y, Nagata Y, Takayama K, Matsuo Y, Sakamoto T, Sakamoto M, Mizowaki T, Yano S, Hiraoka M (2008) Stereotactic body radiotherapy for oligometastatic lung tumors. Int $\mathrm{J}$ Radiat Oncol Biol Phys 72(2):398-403. https://doi.org/10.1016/j. ijrobp.2008.01.002

36. Zhang Y, Xiao JP, Zhang HZ, Yin WB, Hu YM, Song YX, Zhang K, Liao ZX, Li YX (2011) Stereotactic body radiation therapy favors long-term overall survival in patients with lung metastases: five-year experience of a single-institution. Chin Med J (Engl) 124(24):4132-4137

37. de Vin T, Engels B, Gevaert T, Storme G, De Ridder M (2014) Stereotactic radiotherapy for oligometastatic cancer: a prognostic model for survival. Ann Oncol 25(2):467-471. https://doi.org/10. 1093/annonc/mdt537

38. Shioyama Y, Onishi H, Takayama K, Matsuo Y, Takeda A, Yamashita H, Miyakawa A, Murakami N, Aoki M, Matsushita H, Matsumoto Y, Shibamoto Y, Japanese Radiological Society MultiInstitutional SBRT Study Group (JRS-SBRTSG) (2018) Clinical outcomes of stereotactic body radiotherapy for patients with stage I small-cell lung cancer: analysis of a subset of the Japanese radiological society multi-institutional SBRT study group database. Technol Cancer Res Treat 17:1533033818783904. https://doi.org/ $10.1177 / 1533033818783904$

39. Takei H, Kondo H, Miyaoka E, Asamura H, Yoshino I, Date H, Okumura M, Tada H, Fujii Y, Nakanishi Y, Eguchi K, DosakaAkita H, Kobayashi H, Sawabata N, Yokoi K (2014) Surgery for small cell lung cancer: a retrospective analysis of 243 patients from Japanese lung cancer registry in 2004. J Thorac Oncol 9(8):1140-1145. https://doi.org/10.1097/JTO.0000000000000226

40. Roengvoraphoj O, Eze C, Niyazi M, Li M, Hildebrandt G, Fietkau R, Belka C, Manapov F (2017) Prognostic role of patient gender in limited-disease small-cell lung cancer treated with chemoradiotherapy. Strahlenther Onkol 193(2):150-155. https:// doi.org/10.1007/s00066-016-1073-x

41. Helou J, Thibault I, Poon I, Chiang A, Jain S, Soliman H, Erler D, Yeung L, Cheung P (2017) Stereotactic ablative radiation therapy for pulmonary metastases: histology, dose, and indication matter. Int J Radiat Oncol Biol Phys 98(2):419-427. https://doi.org/ 10.1016/j.ijrobp.2017.02.093

42. Takeda A, Kunieda E, Ohashi T, Aoki Y, Koike N, Takeda T (2011) Stereotactic body radiotherapy (SBRT) for oligometastatic lung tumors from colorectal cancer and other primary cancers in comparison with primary lung cancer. Radiother Oncol 101(2):255-259. https://doi.org/10.1016/j.radonc.2011.05.033

43. Thibault I, Poon I, Yeung L, Erler D, Kim A, Keller B, Lochray F, Jain S, Soliman H, Cheung P (2014) Predictive factors for local control in primary and metastatic lung tumours after four to five fraction stereotactic ablative body radiotherapy: a single institution's comprehensive experience. Clin Oncol (R Coll Radiol) 26(11):713-719. https://doi.org/10.1016/j.clon.2014.06.018

44. Nicosia L, Cuccia F, Mazzola R, Ricchetti F, Figlia V, Giaj-Levra N, Rigo M, Tomasini D, Pasinetti N, Corradini S, Ruggieri R, Alongi F (2020) Disease course of lung oligometastatic colorectal cancer treated with stereotactic body radiotherapy. Strahlenther Onkol 196(9):813-820. https://doi.org/10.1007/s00066-020-01627-7

45. Franzese C, Comito T, Toska E, Tozzi A, Clerici E, De Rose F, Franceschini D, Navarria P, Reggiori G, Tomatis S, Scorsetti M (2019) Predictive factors for survival of oligometastatic colorectal cancer treated with stereotactic body radiation therapy. Radiother Oncol 133:220-226. https://doi.org/10.1016/j.radonc.2018.10.024

46. Hamid O, Robert C, Daud A, Hodi FS, Hwu WJ, Kefford R, Wolchok JD, Hersey P, Joseph R, Weber JS, Dronca R, Mitchell TC, 
Patnaik A, Zarour HM, Joshua AM, Zhao Q, Jensen E, Ahsan S, Ibrahim N, Ribas A (2019) Five-year survival outcomes for patients with advanced melanoma treated with pembrolizumab in KEYNOTE-001. Ann Oncol 30(4):582-588. https://doi.org/10. 1093/annonc/mdz011

47. Mazzola R, Ruggieri R, Figlia V, Rigo M, Giaj Levra N, Ricchetti F, Nicosia L, Corradini S, Alongi F (2019) Stereotactic body radiotherapy of central lung malignancies using a simulta- neous integrated protection approach : a prospective observational study. Strahlenther Onkol 195(8):719-724. https://doi.org/10.1007/ s00066-018-01419-0

48. Dhami G, Zeng J, Vesselle HJ, Kinahan PE, Miyaoka RS, Patel SA, Rengan R, Bowen SR (2017) Framework for radiation pneumonitis risk stratification based on anatomic and perfused lung dosimetry. Strahlenther Onkol 193(5):410-418. https://doi.org/10.1007/ s00066-017-1114-0 